\title{
Why do pastures respond to lime?
}

\author{
D.M. WHEELER and M.B. O'CONNOR \\ AgResearch, Ruakura Research Centre, Private Bag 3123, Hamilton, New Zealand
}

\begin{abstract}
Lime responses in pasture have been attributed to amelioration of aluminium (Al) and manganese (Mn) toxicity, increased plant availability of nitrogen $(\mathrm{N})$, phosphorus $(\mathrm{P})$ and molybdenum (Mo), and increased soil moisture. Methods of assessing the occurrence of each of these mechanisms are given, illustrated using results from two contrasting lime trials where mechanisms of lime response were determined. The results indicate that lime responses on the Mangatea soil could be attributed to lime increasing $\mathrm{N}, \mathrm{P}$, and $\mathrm{Mo}$ availability, and to the amelioration of $\mathrm{Al}$ toxicity allowing better access to soil moisture over summer. In contrast, on the Matapiro soil lime responses were owing to enhanced $\mathrm{N}$ mineralisation. The results show that the occurrence and size of a pasture response owing to a given mechanism are owing to interactions between soil factors, plant species and climate. Hence more complex pasture models than are currently available are required before predictions of the size and duration of lime responses can be improved.
\end{abstract}

Keywords: aluminium, lime, manganese, nitrogen, phosphorus, pasture response

\section{Introduction}

From a study of 126 trials, Edmeades et al. (1985) showed that, on average, the response to lime increases as soil $\mathrm{pH}$ decreases. Soil $\mathrm{pH}$ is a measure of the $\mathrm{H}$ ion concentration in solution when water is mixed with the soil. In glasshouse studies, most pasture species can tolerate $\mathrm{H}$ ion concentrations occurring at $\mathrm{pH} 4$. Out of about 90 pasture species screened, only lucerne was sensitive to $\mathrm{pH}$ per se (Wheeler et al. 1992). However, from the many lime trials conducted in New Zealand, it is known that pastures may respond to a soil $\mathrm{pH}$ up to at least 6.0 (Edmeades et al. 1985). Lime responses may be owing to the effect changes in soil $\mathrm{pH}$ have on soil chemical, physical and microbial properties, and can include the amelioration of aluminium (Al) (During \& Brier 1973; Edmeades et al. 1983) and manganese (Mn) toxicity (Smith \& Edmeades 1983b), increased plant availability of nitrogen (N) (Wheeler et al. 1997; Edmeades et al. 1986), phosphorus (P) (Edmeades et al. 1991; Haynes 1983) and molybdenum (Mo) (During 1984), increased soil moisture content (During et al. 1984), or a combination of these.

Although many lime trials have been conducted in New Zealand, only two trials have investigated the range of mechanisms within a site. This paper will discuss how to assess whether a particular mechanism occurs at a given site, using results from these two trials as examples.

\section{Methods}

Trials designed to determine the mechanisms of lime response were conducted on two contrasting sites. The layout, design and measurements made are described by Wheeler (1998) and Edmeades et al. (1991). The first trial was on a Mangatea clay loam, a yellow-brown earth, situated on a sheep and beef farm $8 \mathrm{~km}$ south of Te Kuiti (Wheeler 1998). The site generally has cool winters and warm moist summers, with an annual rainfall of about $1400 \mathrm{~mm}$. The dominant pasture species were ryegrass (Lolium perenne) and white clover (Trifolium repens), although paspalum (Paspalum dilatatum) became more dominant over autumn. The second trial was on a Matapiro silt loam, a yellow-grey earth, situated on a sheep and beef farm about $10 \mathrm{~km}$ east of Hastings. The site has cool winters and hot dry summers, with an annual rainfall of about $800 \mathrm{~mm}$. The dominant pasture species were ryegrass and subterranean clover (Trifolium subterraneum).

At each site, yield, pasture composition, pasture nutrient analysis, and ${ }^{15} \mathrm{~N}$ analysis measurements were made at each cut. Soil samples were taken annually.

\section{Results and Discussion}

\section{Mn toxicity}

Mn toxicity is usually detected by plant analysis, where levels greater than $570 \mu \mathrm{g} \mathrm{Mn} / \mathrm{mg}$ in clover or $1110 \mu \mathrm{g}$ $\mathrm{Mn} / \mathrm{mg}$ in grass are required to reduce plant growth (Smith \& Edmeades 1983a). Soil analysis is unreliable, as Mn toxicity also depends on the redox potential of the soil. Based on plant analysis (Table 1), there was no indication of Mn toxicity on either the Mangatea or 
Matapiro soils. The incidence of lime responses owing to reduced manganese $(\mathrm{Mn})$ toxicity is probably low, as a national survey of pasture $\mathrm{Mn}$ concentrations found less than $2 \%$ of sampled sites had levels that indicated Mn toxicity was a problem (Smith \& Edmeades 1983b).

Table 1 Plant $\mathrm{Mn}$ concentrations and top soil $(0-75 \mathrm{~mm}) \mathrm{CaCl}_{2-}$ extractable $\mathrm{Al}$ and $\mathrm{pH}$ of the no lime treatments.

\begin{tabular}{llcc}
\hline & & Mangatea & Matapiro \\
\hline Plant Mn concentration $(\mu \mathrm{g} / \mathrm{g})$ & Grass & 230 & 230 \\
& Clover & 90 & 120 \\
$\mathrm{Al}\left(0.01 \mathrm{M} \mathrm{CaCl}_{2}\right.$-extractable) & & 2.0 & 2.4 \\
Soil pH & & 5.4 & 5.3 \\
\hline
\end{tabular}

\section{Al toxicity}

Al toxicity is likely to reduce white clover yield when soil Al levels are greater than $3-5 \mu \mathrm{g} / \mathrm{g} \mathrm{CaCl}_{2}$ extractable $\mathrm{Al}$ (Edmeades et al. 1983), although Hume et al. (1988) indicated that this could increase to 9 as soil organic carbon increased. The critical values for grass are probably similar, given that ryegrass has a similar or slightly higher toxicity to $\mathrm{Al}$ than white clover (Wheeler et al. 1992). Al toxicity rarely occurs when the soil $\mathrm{pH}$ is greater than 5.5. On pure peat Al toxicity is not a problem even at low $\mathrm{pH}$. Plant analysis for $\mathrm{Al}$ toxicity is unreliable owing to difficulties in avoiding soil (and thus $\mathrm{Al}$ ) contamination. Based on $\mathrm{CaCl}_{2}$ levels, $\mathrm{Al}$ toxicity is unlikely to be a problem in the topsoil of these soils (Table 1).

In most soils, Al toxicity is more likely in the subsoil than the topsoil. This can sometimes be manifested as poor root penetration into the subsoil, leading to the pasture being more susceptible to drought, pasture pulling or nutrient deficiencies. As most lime is surface applied, there must be sufficient time for the lime to move down to the depth where the toxic levels of $\mathrm{Al}$ occur. The change in soil $\mathrm{pH}$ at 4 depths 5 years after lime was applied (Figure 1) shows that lime moved deeper and faster on the Mangatea soil than on the
Matapiro soil. These changes are typical of the range found on North Island soils (Wheeler 1997a, b) for soils from wetter (Mangatea soil) or drier (Matapiro) sites.

For the Mangatea soil, the differences between replicate data over summer (Table 2) suggest that lime could be ameliorating subsoil Al toxicity and allowing improved root access to soil moisture in the subsoil of reps 1 and 2. The lack of response to lime in reps 3 and 4 could be owing to the lower Al levels, higher surface soil moisture making the plants less reliant on subsoil moisture over summer, or the higher Al tolerance of paspalum compared with ryegrass (Wheeler et al. 1992). These results illustrates the sort of variation that can occur in the field, and how pasture species, subsoil Al and soil moisture conditions can interact to give responses to lime.

Table 2 Differences between replicates in the trial on the Mangatea soil.

\begin{tabular}{lcc}
\hline & Reps 1\&2 & Reps 3 \& 4 \\
\hline lime response & yes & no \\
topsoil soil moisture in summer & drier & moister \\
subsoil KCl extractable Al & higher & lower \\
dominant grass in summer & ryegrass & paspalum \\
\hline
\end{tabular}

\section{Soil moisture}

In general, increases in soil moisture from liming are often small $(<5 \%)$ and occur over a short time period ( $<7$ days), probably because of increases in infiltration rates (Watt \& Crouchley 1985) and changes in the hydrophobicity of the soil (S. Orr, pers. comm.). Watt \& Crouchley (1985) also showed that lime plots wetted up more evenly than unlimed plots. A disadvantage of the increased soil moisture in the topsoil was an observed increase in pugging damage. In general, there is insufficient information to be able to predict the likely effect of lime on soil moisture at a given site, or the likely effects of these changes on yield.

Figure 1 Difference in soil pH between the lime and no lime treatments at 4 depths 5 years after the application of lime.

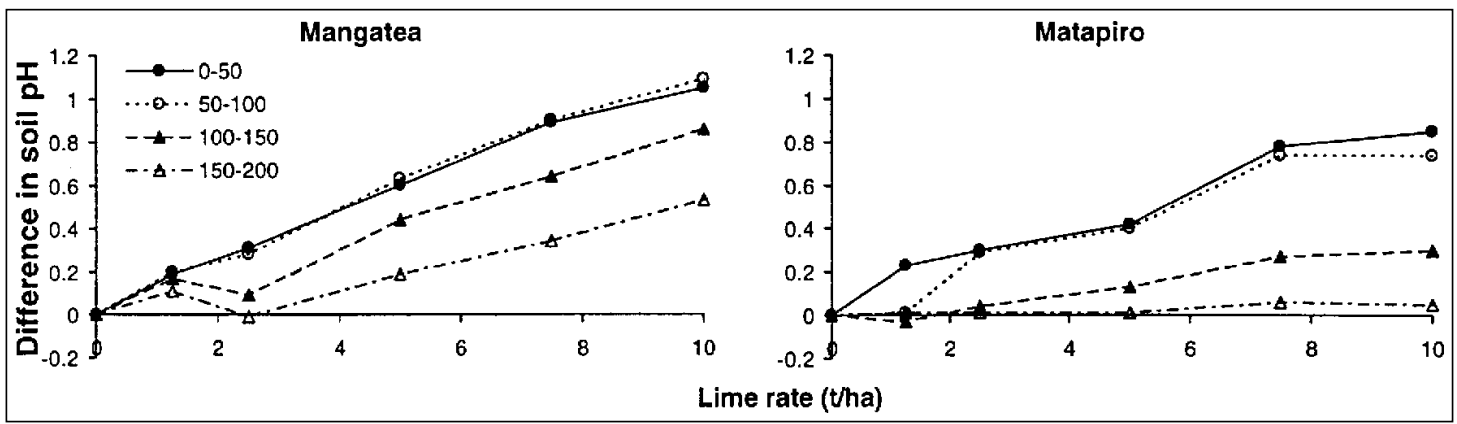




\section{Mo availability}

Lime increased plant Mo concentrations on both these soils (Table 3), as predicted by During (1984). However, clover responses to Mo are expected when plant Mo concentrations are less than $0.1 \mathrm{ppm}$ (Cornforth \& Sinclair 1984). On the Mangatea soil, plant Mo concentrations in clover taken from the no Mo treatment (Table 3 ) were generally below $0.1 \mathrm{ppm}$, indicating Mo deficiency. Hence the lime-induced increase in Mo availability led to increased clover growth followed by increased grass growth (Wheeler 1998). In contrast, on the Matapiro soil, plant Mo concentrations were generally always greater than $0.1 \mathrm{ppm}$ and thus sufficient, and hence the lime-induced increase in Mo availability had no affect on yield (results not presented).

Table 3 Mean annual clover Mo concentrations $(\mu \mathrm{g} / \mathrm{g})$.

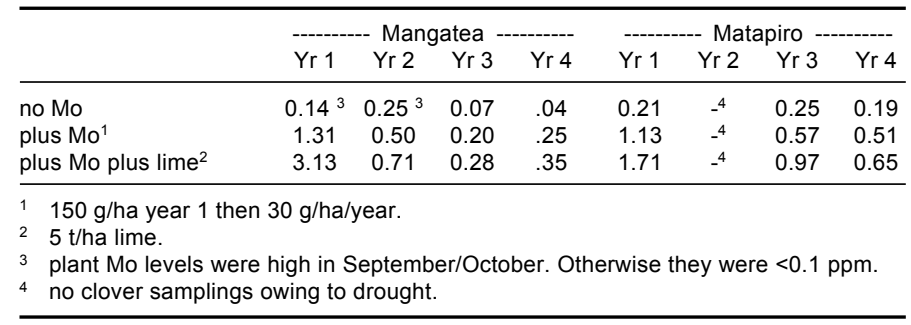

\section{N availability}

The increase in the amount of net $\mathrm{N}$ mineralised has been measured using the ${ }^{15} \mathrm{~N}$ dilution technique in 3 mowing trials (Table 4) and 1 grazing trial (Wheeler $e t$ al. 1997). This increase in net $\mathrm{N}$ mineralisation has been associated with lime increasing microbial activity rather than microbial numbers (Edmeades et al. 1981). In common with overseas reports (Nyborg \& Hoyt 1978), the lime-induced increase in net $\mathrm{N}$ mineralisation appears to last only 2-3 years. For the first 2 years, the average annual amount of net $\mathrm{N}$ mineralised on the mowing trials increased with lime rate such that net $\mathrm{N}$ mineralised $(\mathrm{kg} \mathrm{N} / \mathrm{ha} / \mathrm{yr})$ was $3.3 *$ lime rate $(\mathrm{t} / \mathrm{ha})$.

Nitrogen availability can also be increased by lime increasing clover growth (e.g., owing to increases $\mathrm{P}$ or Mo availability, alleviation of Al toxicity), and a

Table 4 Annual increase in net $\mathrm{N}$ mineralised (kg N/ha/year) after the application of lime ( $\mathrm{t} / \mathrm{ha}$ ).

\begin{tabular}{lccccccc}
\hline Soil & Lime rate & Yr 1 & Yr 2 & Yr 3 & Yr 4 & Yr 5 & Yr 1 \& 2 \\
\hline Matapiro $^{1}$ & 5 & 25 & 14 & -9 & -13 & 2 & 39 \\
& 10 & 33 & 31 & -1 & -7 & 3 & 64 \\
Mangatea $^{1}$ & 5 & 6 & 19 & 9 & -4 & & 25 \\
& 10 & 13 & 58 & 27 & 6 & & 71 \\
Stratford $^{2}$ & 7.5 & & & & & & 50 \\
\hline
\end{tabular}

see Wheeler et al. (1997)

2 see Edmeades et al. (1983) subsequent transfer of $\mathrm{N}$ from clover (derived mainly from $\mathrm{N}$ fixation) to grass (Whitehead 1995; Ledgard 1991). In mowing trials, there is a delay in this transfer, typically up to 6 months (Ledgard 1991; Edmeades et al. 1991; Wheeler 1998). This can lead to a pattern of growth whereby a clover response is followed by a grass response. Such patterns have been reported for lime and P on the Matapiro soil (Edmeades et al. 1991) and for Mo and P on the Mangatea soil (Wheeler 1998). In grazing trials, the pattern is probably more diffuse as $\mathrm{N}$ is being added in a readily available form (urine).

\section{$P$ availability}

Lime can increase plant $\mathrm{P}$ concentrations and plant $\mathrm{P}$ uptake by either increasing the ability of the plant to use available soil P (e.g., by amelioration of Al or Mn toxicity) or increasing the amount of plant-available $\mathrm{P}$ in the soil per se (P-sparing effect). Mansell et al. (1984) found that P-sparing typically occurred on sedimentary soils with a soil $\mathrm{pH}$ less than 5.5. On sites where P-sparing did occur, it did not necessarily occur in every season, or in every year (Mansell et al. 1984).

The results from the two studies of mechanisms of lime response suggest that the occurrence and size of any yield response from Psparing depends on other factors such as the soil $\mathrm{N}$ and $\mathrm{P}$ status, species and climate. For example, on the Mangatea soil, P-sparing increased yield only in the clover over summer when clover $\mathrm{P}$ concentrations where below the optimum concentrations required for plant growth (Wheeler 1998). The P-sparing had no effect on grass yield, as grass $\mathrm{P}$ concentrations were always above optimum concentrations. The plant $\mathrm{P}$ concentrations in clover varied because of the normal seasonal variation in plant $P$ concentrations found on this site, and because of the overall change in $\mathrm{P}$ concentrations over time owing to fertiliser P applications. In contrast, on the Matapiro soil, P-sparing increased yield in the spring of years 3 and 4 (Edmeades et al. 1991). Although both clover and ryegrass were $\mathrm{P}$ deficient, the $\mathrm{P}$-sparing effect on yield was initially seen in the clover then in the grass. As the grass on this soil was more $\mathrm{N}$ deficient than $\mathrm{P}$ deficient, it is possible that $\mathrm{P}$-sparing was observed in grass only when there was sufficient $\mathrm{N}$, owing to the transfer of $\mathrm{N}$ from clover to grass, to allow good grass growth.

\section{Duration of lime response}

The duration of lime response (i.e., the time taken for a lime-treated soil $\mathrm{pH}$ to return to its initial $\mathrm{pH}$ ) in the topsoil was estimated from the rate of decrease in $\mathrm{pH}$ 
after a maximum $\mathrm{pH}$ was achieved. The duration was estimated as being 11 years in the Mangatea soil and 17 years on the Matapiro soil. These durations are longer than those predicted using the equations given by Edmeades et al. (1985) based on South Island data. In both soils, the duration was largely independent of the lime rate, which also contrasts with Edmeades' equations, where the duration depended on the lime rate used. The reasons for these differences are not known.

On the Mangatea trial, there were lime responses for the each of the 4 years that measurements were made (Wheeler 1998). On the Matapiro soil there were lime responses in the first 2 out of 5 years on the mowing trial (Edmeades et al., 1991), and for the first 3 out of 17 years on an adjacent grazing trial (Morton et al. 1998). These results indicate that calculating economic outcomes of lime based on changes in soil $\mathrm{pH}$ could be misleading, particularly on soils such as the Matapiro. A better understanding of the mechanisms that operate at a given site may better indicate the duration of lime responses.

\section{Summary}

The above results indicate that there are multiple mechanisms for lime response, and that the combination of mechanisms that occur at a given site does vary. Thus on the Mangatea soil, lime responses could be attributed to lime increasing $\mathrm{N}, \mathrm{P}$ and Mo availability, and to amelioration of $\mathrm{Al}$ toxicity allowing better access to soil moisture over summer. In contrast, on the Matapiro soil, lime responses were owing to enhanced mineralisation, and possibly to small increases in the availability of $P$.

Currently, soil or plant testing can be used to determine only whether some of the mechanisms are likely to occur at a given site. However, information on the likely occurrence of specific mechanisms can be useful. For example, if the mechanism involves amelioration of subsoil toxicities, then time is needed for lime to move down the soil profile before a response will be seen. The interactions that occur within a soil (e.g., between P-sparing, N and P cycling, species and climate, or between Al toxicity, soil moisture and species) mean that more complex pasture models than are currently available are probably required before predictions of the size and duration of lime responses can improve.

\section{REFERENCES}

Cornforth, I. S.; Sinclair, A. 1984. 'Fertiliser and lime recommendations for pastures and crops in New
Zealand'. $2^{\text {nd }}$ rev. ed. New Zealand Ministry of Agriculture and Fisheries, Wellington.

During, C. 1984. Fertiliser and soils in New Zealand farming. Wellington, Government Printer.

During, C.; Brier, G.J. 1973. Prediction of lime responses in white clover: a note. New Zealand journal of agricultural research 16: 9-11.

During, C.; Jackson, L.J.; Dyson, C.B. 1984. Lime effects of hill country 2. Relation of soil moisture, $\mathrm{pH}$, and aluminium values with pasture yield. New Zealand journal of agricultural research 27: 531535.

Edmeades, D.C.; Judd, M.; Sarathchandra, S.U. 1981. The effect of lime on nitrogen mineralization as measured by grass growth. Plant and soil 60: 177186.

Edmeades, D.C.; Smart, C.E.; Wheeler, D.M. 1983. Aluminium toxicity in New Zealand soils: preliminary results on the development of diagnostic criteria. New Zealand journal of agricultural research 26: 493-501.

Edmeades, D.C.; Pringle, R.M.; Mansell, G.P.; Shannon, P.W.; Ritchie J.; Stewart, K.M. 1985. Effects of lime on pasture production on soils in the North Island of New Zealand 5. Description of a lime recommendation scheme. New Zealand journal of experimental agriculture 13: 47-58.

Edmeades, D.C.; Rys, G.; Smart, C.E.; Wheeler, D.M. 1986. Effect of lime on soil-nitrogen uptake by a ryegrass-white clover pasture. New Zealand journal of agricultural research 29: 49-53.

Edmeades, D.C.; Wheeler, D.M.; Rys, G.J.; Smith, N.B. 1991. Effect of pasture composition on lime and phosphorus responses on a dryland soil. Proceedings of the New Zealand grassland association conference 52: 171-175.

Haynes, R.J. 1983. Effect of lime on phosphate availability in acid soils. A critical review. Plant and soil 68: 289-308.

Hume, L.J.; Ofsoski, N.J.; Reynolds, J. 1988. Influence of $\mathrm{pH}$, exchangeable aluminium and $0.02 \mathrm{M} \mathrm{CaCl}_{2}$ extractable aluminium on the growth and nitrogenfixing activity of white clover (Trifolium repens) in some New Zealand soils. Plant and soil 111: 111119.

Ledgard, S.F. 1991. Transfer of fixed nitrogen from white clover to associated grasses in swards grazed by dairy cows, estimated using $\mathrm{N}^{15}$ methods. Plant and soil 131: 215-223.

Mansell, G.P.; Pringle, R.M.; Edmeades, D.C.; Shannon, P.W. 1984. Effects of lime on pasture production on soils in the North island of New Zealand. 3. Interaction of lime with phosphorus. New Zealand journal of agricultural research 27: 363-369. 
Morton, J.D.; Wheeler, D.M.; Smith, N.S. 1998. Effect of lime and form of superphosphate on productivity of dryland pastures. New Zealand journal of agricultural research 41: 65-74.

Nyborg, M.; Hoyt, P.B. 1978. Effects of soil acidity and liming on mineralisation of soil nitrogen. Canadian journal of soil science 58: 331-338.

Smith, G.S.; Edmeades, D.C. 1983a. Manganese status of New Zealand pastures. 1. Toxicity in ryegrass, white clover, and lucerne. New Zealand journal of agricultural research 26: 215-221.

Smith, G.S.; Edmeades, D.C. 1983b. Manganese status of New Zealand pastures. 2. Pasture concentrations. New Zealand journal of agricultural research 26 : 223-225.

Watt, J.P.C.; Crouchley, G. 1985. Observations of season variability of hydraulic properties at the soil surface and the effects of lime. In: Proceedings of the Soil Dynamic and Land Use Seminar, Blenheim, New Zealand.

Wheeler, D.M. 1997a. Predicting the change in $\mathrm{pH}$ at various depths 5 years after the surface application of lime for some New Zealand subsoils. New Zealand soil news 45: 21-25.

Wheeler, D.M. 1997b. Temporal changes in some soil chemical properties at four depths following the surface application of lime. New Zealand journal of agricultural research 40: 309-316.

Wheeler, D.M. 1998. Investigation into the mechanisms causing lime responses in a grass/clover pasture on a Mangatea soil, New Zealand. New Zealand journal of agricultural research: (In press).

Wheeler, D.M.; Edmeades, D.C.; Morton J.D. 1997. Effect of lime on yield, $\mathrm{N}$ fixation and soil $\mathrm{N}$ uptake on 3 contrasting trials in New Zealand. New Zealand journal of agricultural research 40: 397-408.

Wheeler, D.M.; Edmeades, D.C.; Christie, R.A.; Gardner, R.C. 1992. Effect of aluminium on the growth of 34 plant species: A summary of results obtained in low ionic strength solution culture. Plant and soil 146: 61-66.

Whitehead, D.C. 1995. Grasslands nitrogen. Oxford, CAB International. 
